DOI: $10.15838 / \mathrm{esc} / 2015.2 .38 .6$

UDC 621.311 : 332.1 (470.13), LBC 65.04.31.19 (2Rus.Kom)

(C) Chaika L.V.

\title{
The priorities of the energy infrastructure modernization in rural areas of the Komi Republic
}

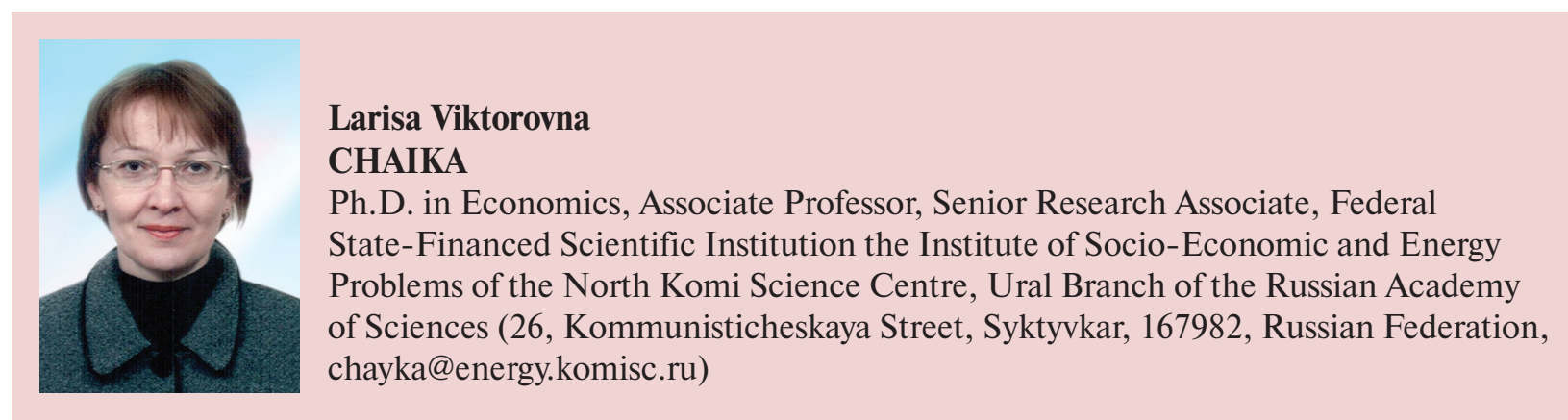

Abstract. The article presents the problems of development and modernization of energy infrastructure priorities in rural areas of the Komi Republic. For the most part of rural population the achieved level of energy supply is the necessary minimum for the needs, and it has the low parameters of the energy and economy efficiency. The main directions of the rural energy supply modernization should be: the gas supply system development, the electric grid capacity growth and the construction of the modern small energy technologies (small central heating and power plants, modular boiler plants, efficient solid fuel boilers).

Key words: Komi Republic, rural settlements, integrated energy supply, energy infrastructure, level of development, efficiency, modernization.

Power supply in the rural settlements of the Komi Republic is much more inferior to that in the cities in terms of availability and cost of energy services. The problem of modernization of rural energy supply in the Republic is acute due to the significant depreciation of the equipment, the large number of inhabitants for whom energy supply is costly (more than 110 thousand people), and also due to the need for budgetary subsidies (almost 6 billion rubles for 4 years [1]). In this regard, regional studies of the issues of rural energy development are relevant because they focus on systematizing economic and power conditions and choosing modernization priorities.

This article presents the specifics of development of energy infrastructure (EI) in the rural settlements of the Komi Republic, and identifies modernization problems and priorities. 
After analyzing EI in the rural areas [2] it was possible to identify the main shortcomings of its development: the low level of gasification gas network, the presence of areas with decentralized power supply, the high share of inefficient heat supply. Taking into account the specifics of the structural organization of energy supply in the rural settlements of the Republic, we have defined the six levels of development of energy infrastructure - from the zero to the fifth level, each of them is characterized by a certain set of elements (table).

The assessment of this indicator for the Republic's settlements allowed us to carry out economic mapping (figure), which shows the territorial differentiation of the energy supply conditions and which can be used as information basis for regional planning.

The higher the level of development, the more developed the system of energy supply, the higher its development potential and production efficiency. We understand the potential as the summary characteristic of system features such as the degree of integration of energy services provision, the availability of opportunities for structural development, and the diversification of technologies. Comparative effectiveness reflects modern price terms: the advantages of gas generation, the high cost of decentralized power supply and local heat supply with small load and remote delivery of fuel. The overall assessment of the development of EI in the rural areas in general in the Republic leads to the following distribution:

- 97 rural settlements with the total population of 63.7 thousand people have a relatively high potential of EI (level 4 and 5), they comprise 34 gasified and 63 nongasified settlements situated close to the Republic's energy and transport centers, which have a relatively efficient integrated power supply of consumers;

Distribution of rural settlements by level of development of energy supply, 2012

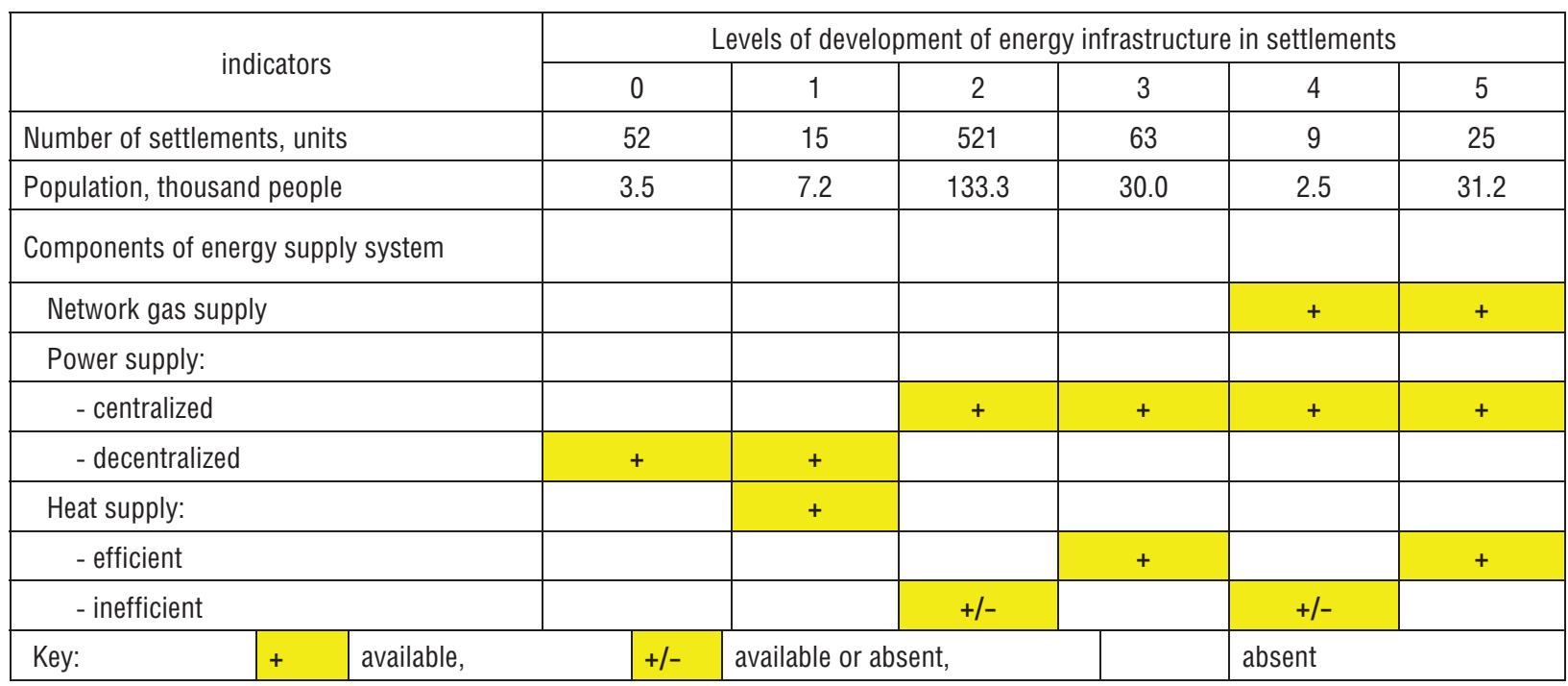




\section{The territorial differentiation of the energy supply conditions}

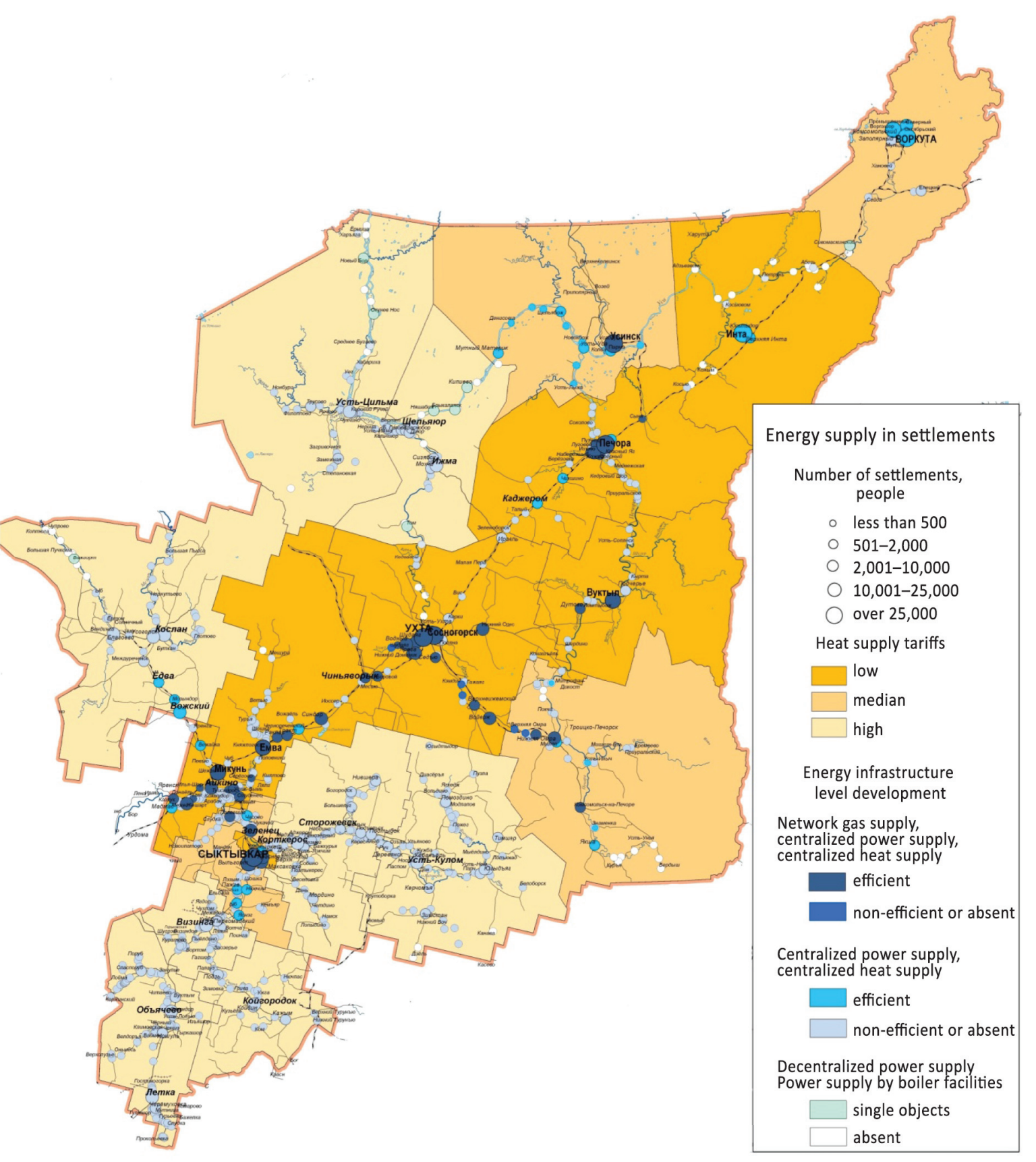


- the average potential of the energy infrastructure is typical of the majority of rural settlements (521) with the total population of 133.3 thousand people these are the settlements remote from the Republic's energy and transport centers that have centralized power supply, but their heat supply is very expensive, since it is provided by small boiler facilities or by those that use only furnace heating;

- 67 rural settlements with the total population of 10.7 thousand people have the low potential of energy infrastructure; these are the rural settlements located in the most peripheral areas of the Republic; they have costly decentralized power supply provided by diesel generators, with or without heat supply, and high costs of fuel delivery.

Consequently, the majority $(70 \%)$ of the rural population lives in rural settlements, in which the level of development of EI is not higher than the second; this level satisfies the minimum necessary needs, but the energy and economic efficiency of energy supply remains very poor. The priorities in planning the energy sector modernization should include the selection and implementation of optimal technological solutions to replace the inefficient heat supply and the expensive decentralized power supply. The prospects of development of EI in the rural areas are related to the further gasification and power grid construction, and to the large-scale upgrading of local energy sources based on modern technology.
Gasification. The development of gas distribution system is of paramount importance in the formation of energy infrastructure, in ensuring quality, efficient and environmentally friendly energy supply. But in the medium term, it is not planned to expand significantly the zones of network gas supply in the rural areas of the Republic (according to the schemes developed by OAO Gazprom Promgaz). This is impeded by the remoteness and low density of energy load, which result in extremely high unit costs to the distribution system. The projects of the most complete gasification of consumers in rural settlements are implemented most often, if these settlements are already partially connected to the gas supply network and which are subject to financial support provided from the budget.

Further development of gas supply in the Republic is connected with the construction of the Bovanenkovo-UkhtaTorzhok main gas pipeline, the two strings of which are planned to be put into operation in 2016. The main gas pipeline in the Komi Republic goes through seven municipalities and includes the districts of Vorkuta and Inta, thus creating an opportunity for their subsequent gasification.

Autonomous gasification with the use of liquefied natural gas (LNG) or liquefied petroleum gas (LPG) is a possible option for the development of high-quality energy supply in remote settlements. Gas in the LNG option is liquefied at a mini plant located near the pipeline, then it is delivered by special vehicles to the place of its use. 
The gas is kept in liquid form in cryogenic insulated tanks, and before it is used it goes through the regasification system and is directed to industrial facilities and residential buildings via local networks. When gasification is based on the use of LPG, the fuel is delivered by trucks and stored in tanks under pressure (gas tanks). Currently, the settlements that do not have network gas supply use imported LPG, mainly in cylinders, as fuel for household purposes. Norms of consumption are established for the population, limit values are established for the prices, and budget subsidies to compensate for the loss of income are allocated to the suppliers. But even if the prices of LPG are preferential for the population, the costs to the consumers are much higher in comparison to network gas supply.

Widespread use of liquefied gas as fuel for boiler facilities is limited by its high cost. Prices for liquefied gas ( $\mathrm{LNG}$ and LPG) not less than 3 times exceed the cost of network natural gas in energycomparable measurement; and the fuel component of the cost of heat energy production is more expensive, accordingly ${ }^{1}$. Therefore, the use of liquefied gas in heat supply systems in rural settlements should be viewed primarily as an expensive, but more competitive and environmentally friendly alternative to boiler facilities that work on fuel oil.

The competitiveness of LNG, as compared to the option of development of

\footnotetext{
1 See: http://www.gazpromlpg.ru/index.php?id=184.
}

network gas supply, according to the estimate [3], can be achieved only if settlements are located very far from the source of gas supply (more than 0.5-1.2 thousand $\mathrm{km}$ ) and if the volume of gas consumption is small (5-25 tons/year); and if the distance does not exceed $200 \mathrm{~km}$, then the integral costs of setting up a standalone LNG-based gasification system are several times higher than the costs of constructing an inter-village network.

Taking into account the differences in prices, it is obvious that the introduction of autonomous gas supply technology in the rural areas of the Republic will require government support and subsidies; the further network gasification of the Republic's rural settlements will require the same measures. Competitive advantages of alternative options should be assessed taking into consideration the development of a scheme of gas supply of the Republic and the complex energy supply schemes for municipalities.

Local energy sources. The share of inefficient capacities in the total performance indicators of heating plants in rural areas (with production costs exceeding the limit rate of the tariff) reaches $61 \%(218)$ of their total number and $46 \%(352 \mathrm{Gcal} / \mathrm{h})$ in the total installed capacity. The well-grounded choice of the best technological solutions to replace more than 200 outdated boiler facilities in 134 rural settlements of the Republic and the implementation if these solutions is a priority in planning the modernization of heat supply [2]. 
Currently, according to JSC Komi Heating Company ${ }^{2}$, the rural areas of the Republic are planning and implementing the projects for the construction of new modular boiler facilities; several boiler plants are being reconstructed so that they could work on gas or coal rather than on fuel oil; obsolete boilers are being replaced, small inefficient boiler facilities are being shut down and replaced by electric heating systems. The number of inefficient boiler plants for the last 4 years has decreased by 47 units; 32 unprofitable boiler facilities have been closed[1].

However, it should be noted that the shift from small boiler plants to electric heating is not a cost-effective and energy efficient solution. The heat supply organization explains this solution by the decrease in damage, but at that the actual cost of heating to consumers (or the need for budget subsidies) can increase. Electricity is the most expensive energy source with low production efficiency and high transmission losses, and its use for heating is the most energy-wasteful and expensive heating option: at the cost of electric power being five rubles per $\mathrm{kW}^{*} \mathrm{~h}$ the production of one Gcal of useful heat will cost six thousand rubles (if the efficiency of electric heaters is $98 \%$, excluding the cost of amplification of electric grids and heat losses in heated rooms), and the utilization efficiency of primary energy of the fuel will not exceed $30 \%$.

\footnotetext{
2 http://komitk.ru
}

In general, the rates and coverage of modernization in the heat economy of rural areas remain low and insufficient for making qualitative changes in the situation that concerns heat supply efficiency. The reason for this lies in the limited investment resources generated from the tariffs. The comprehensive upgrading of heating systems requires the replacement of a large volume of obsolete boiler equipment and worn-out networks with their modern counterparts or alternative technologies.

In the conditions, when there are many similar objects that require reconstruction, it is important to elaborate in details the solutions for choosing really efficient modernization projects or replacing heatand-power equipment. It is necessary to form the fundamental concept of reconstruction based on a thorough and comprehensive analysis of the composition and characteristics of the existing boiler facilities, options of solid fuel burning and types of mass-produced domestic boilers [4]. When planning the modernization of heat supply systems it is necessary to pay considerable attention to identifying the reserves of energy efficiency of consumption and reducing excessive losses in networks, which in some rural settlements reach $50 \%$ of heat generation (according to the statements of the branches of JSC Komi Heating Company).

Given the magnitude of the task of developing efficient heat supply in rural areas, we can point out that it would be reasonable to organize target program-based 
management of modernization process for the system of energy infrastructure in order to establish systemic interaction between the authorities and business, to coordinate the processes of planning, financing, budget support and project implementation. The priority directions of modernization of heat generating plants in the Republic's rural areas should be as follows: the technology of small CHP, modular boiler facilities of small capacity, efficient solid fuel boilers, generation of energy from wood waste.

Small and mini-CHP. Combined generation of heat and electricity should be carried out in order to improve energy efficiency at the objects under construction or reconstruction, which have heat output of more than five Gcal/h (according to the Resolution of the RF Government dated December 31, 2009 No. 1221). Heat sources with such capacity in the Republic's rural areas include mainly gas and fuel oil boilers that are located in the largest villages where industrial heat consumers are located. The main directions of small and mini-CHP developmen in rural areas include: the construction of small and mini-CHPs by units of $0.5-5 \mathrm{MW}$ with gas turbine units (GTU), small and miniCHPs with internal combustion engines and heat recovery, gas-producing small and mini-CHPs; the reconstruction of gas boiler facilities with the installation of gas turbine or gas-piston units; the installation of steam engines to generate electricity or drive the mechanisms of own needs when boiler plants with steam boilers are being reconstructed [5].
The competitiveness of different small and mini-CHPs depends on technological and local conditions. For instance, small and mini-CHPs with GTU are most suitable for large industrial enterprises that have significant (over 8...10 MW) electric load, their own production base, highly qualified personnel to operate the plant, and that use high pressure gas.

Some favorable prerequisites for the reconstruction of boiler houses with the installation of power generating equipment on the basis of GTU are the availability of year-round consumption of heat, the presence of a gas pipeline with the pressure not lower than $2.5 \mathrm{MPa}$ or the possibility of installing a booster compressor station on site; the limitations can be as follows: the level of noise from the gas turbine units when boiler facilities are located in a residential area [5].

During the installation of power generating units in boiler facilities, the choice of installed capacity corresponding to the basic heat load of the boilers would be the most economical option.

During the reconstruction of steamgenerating boilers it is efficient to use rotary steam engines (RSE) to produce electric power when the coolant's pressure falls. If the boiler facility has an unused steam pressure fall of 3-6 bar with the consumption of $6-50$ tons/h, then the use of RSE allows for receiving additional electric power of 200-1500 kW [6]. Economic effect from the installation of RSE in existing industrial boiler facilities increases with the increase of boiler steam capacity [7]. 
It can be efficient to use mini CHPs with gas-piston units (GPU) as the main source of electric and thermal power at large agricultural facilities (greenhouses, poultry farms and cattle-breeding complexes). In the power range up to $3.5 \mathrm{MW}$ GPU are more efficient than gas turbines - the unit cost is lower, as well as operating costs [8]. The advantages of new mini-CHPs with GPU in comparison to gas turbine units are as follows: the ability to work on the low- and medium-pressure gas without a supply of high-pressure gas and without gas booster compressors; a more favorable ratio of electric power to thermal power that results in the production of more electricity in a combined way; a longer (2.5-3 times) time between overhaul and a greater total working service; a short period of construction and commissioning, more economical operation at partial load. The absence of restrictions on gas pressure is particularly important for these facilities: for the units with the capacity of $1-1.5 \mathrm{MW}$ the pressure of household gas is enough (less than $0.02 \mathrm{MPa}$ ), for more powerful units the required pressure does not exceed $0.6 \mathrm{MPa}$, which is present in any heating plant [8].

The Yaroslavl Oblast (JSC Yaroslavl Generating Company) has positive experience in the projects for reconstruction of gas boilers with the introduction of cogeneration plants. The boiler facilities with the capacity up to $3 \mathrm{Gcal} / \mathrm{h}$ use GPU that have the power up to $300 \mathrm{~kW}$ and are manufactured in Russia. The units operate in cogeneration to cover the year-round needs for hot water and generate electricity for their own needs or for transferring it in the network [9]. The GTK 195 unit is mainly used; it is created on the basis of the YaMZ-240 NM2 engine, modified to work on natural gas, the electric power of the unit is $195 \mathrm{~kW}$ and the heat power is 330 $\mathrm{kW}$, the performance coefficient of the unit is $87.3 \%$. The project was implemented with the participation of the Russian-German enterprise Energy World - Yaroslavl. The installation of GPU in gas boiler facilities in rural areas of the Komi Republic (18 facilities) would allow for producing approximately $20 \mathrm{MW}$ of additional electric power.

The modernization of decentralized power supply to remote consumers remains an important issue in the Komi Republic. During the reconstruction of existing DPPs or construction of new DPPs it is necessary to ensure full utilization of heat energy in order to use expensive diesel fuel to the fullest extent. The utilization coefficient of the heat of fuel combustion in diesel miniCHPs is $75-85 \%$, the production of heat about one MW per one MW of electric power. On the basis of domestic massproduced diesel generators it is possible to create mini-CHPs with heat recovery capacity from $200 \mathrm{~kW}$ to several MW, and also there exists an extensive product range of foreign equipment and the experience of its implementation in Russia.

Replacement of solid fuel boilers. The rural areas of the Komi Republic, as well as Russia as a whole, are characterized by the presence of a significant number 
of coal-fueled boiler facilities of small capacity, most of which are equipped with cast-iron sectional boilers and welded steel boilers with unit capacity of up to $1 \mathrm{Gcal} / \mathrm{h}$ with manual operation. The work of such boilers is characterized by low operational efficiency (30-40\%), poor environmental performance, difficult working conditions of the operating personnel. The following reconstruction measures are proposed depending on the capacity of boilers [4]: under $1 \mathrm{MW}$ - the replacement of existing worn-out and obsolete boilers with new hand-fired boilers; 1-2 MW - the replacement of new boilers with boilers with mechanical stoking; over $2 \mathrm{MW}-$ it is advisable to install boiler units with high temperature fluidized bed technology which makes it possible to use any type of solid fuel, including low-grade coal and wood waste.

The use of wood fuel. The Komi Republic is implementing the sub-program "The use of low-grade wood and wood waste as fuel to produce hot water, heat energy and electricity" (to the regional program "Energy saving and increase of energy efficiency in the Komi Republic (20102020)". The goals set out under the Program for 2013-2016 include the development of production of fuel pellets, fuel briquettes and fuel chips; the substitution of coal for wood fuel briquettes in utility boiler facilities; the construction (reconstruction) of the power sources that use wood fuel.

The Republic is building small-scale CHPs with wood waste utilization: LLC SevLesPil is completing the construction of mini-CHP (with 2.3 MW of electric power and $11 \mathrm{MW}$ of thermal power) operating on wood waste from its primary production; LLC Bioenergy Company has started to implement the project of a small heat power plant in Syktyvkar (with the planned electrical capacity of 4.3 MW and heat capacity of 13-15 MW), which will utilize production waste from landfill sites of Syktyvkar LDK [1]. The project of Bioenergy Company is implemented with the help of allocations from the extra-budgetary fund for energy conservation, which is formed at the expense of tariff sources (911 million rubles) [10]. Unfortunately, the planned efficiency of these projects is not highlighted; the published data make it obvious that the unit cost of power is very high. The economic feasibility of investing in costly cogeneration for the single purpose of disposal of waste that is exceptionally inferior as fuel, raises doubts.

The transfer of heat-generating facilities on wood biofuel requires the regular and timely supply of the necessary amount of fuel during the year, its stable quality and price parameters (fixed price within 5-10 years, minimum transportation costs) $[11,12]$. Wood fuel is burned in furnaces with stationary grates, mechanical grates, fluidized bed, swirling-type furnaces, equipment for pellet combustion [12, 13]. In boiler facilities of small capacity the most common technology is to burn on stationary furnace grates (equipment is cheaper, but the maintenance is more labor intensive and efficiency is low). 
Although the installations with moving and reciprocating grates are expensive, they provide complete combustion at the variable and high humidity of wood waste, swirling-type furnaces are used for fine-fraction fuel [13, 14]. In large boilers it is recommended to use fluidized bed technology, especially for wet waste [14, 15]. In general, the lower the quality of wood fuel, the higher the cost of equipment and the more expensive heat production; as for the choice of incineration technology and boiler equipment, it depends on the humidity, type and composition of wood waste and on the capacity of the unit.

\section{Management development tasks}

Medium-term planning is carried out at the regional level and of crucial importance is the feasibility study of projects for development of EI, which proves their necessity and effectiveness, as well as addressing the issues of investment and program management. But, as a rule, the approved regional and municipal documents (regional scheme and program for development of power industry, energy conservation programs, heat supply schemes, programs for complex development of communal infrastructure systems) have no substantiation of the planned projects and measures to support their implementation. It is the lack of a necessary elaboration of project initiatives, which is one of the main reasons for their long-term delay, given the fact that they are constantly declared in a series of policy documents. Only an accurate assessment of the value of development projects, their effects and necessary funds will make it possible to set priorities and determine the mechanism of their implementation.

In order to stimulate the processes of modernization of power supply systems at all the levels of territorial administration, it is necessary to enhance energy-economic forecasting and planning. Decision making should be based on integrated planning taking into account territorial and functional interconnections of the energy supply system rather than on the formal set of projects and proposals from energy companies (which show the existing policy documents). It is expedient to elaborate future schemes for the development of power supply in rural settlements in order to choose the best option among the available alternatives on the basis of advanced technologies.

The program management of energy development based on infrastructure significance should be carried out, primarily, with the help of public (state and municipal) investment. The Republic has a relatively large source of extra-budgetary funds, which is formed by a percentage markup to energy tariffs (energy saving fund) and which should be used with maximum efficiency for the financial support of the projects for modernization of power supply systems, first of all, communal heat supply.

It should be recognized that the establishment and operation of energy facilities in the northern undeveloped areas is objectively accompanied by increased costs; at that the commercial efficiency of energy supply is limited by tariff regulation 
and isolation of markets. Such conditions cannot be attractive for private business. Therefore it is necessary to encouraging private investment in the development of energy infrastructure in the areas with the help of measures such as subsidies, longterm contracts, special pricing terms, tax incentives, etc.

\section{References}

1. Doklad Glavy Respubliki Komi Vyacheslava Gaizera Gosudarstvennomu Sovetu Respubliki Komi "Ob itogakh deyatel'nosti Pravitel'stva v 2013 godu, ob osnovnykh napravleniyakh raboty na 2014 god i srednesrochnuyu perspektivu” [The Report of Vyacheslav Gaizer, Head of the Komi Republic, to the State Council of the Komi Republic "On the Results of Performance of the Government in 2013, on the Main Directions of Work for 2014 and for the Medium Term]. Available at: http://rkomi.ru/services/doklady/

2. Chaika L.V. Energeticheskaya infrastruktura sel'skikh poselenii Respubliki Komi [Energy Infrastructure in Rural Settlements of the Komi Republic]. Aktual'nye problemy, napravleniya i mekhanizmy razvitiya proizvoditel'nykh sil Severa - 2014: Materialy IV Vserossiiskogo seminara (g. Syktyvkar, 24-26 sentyabrya 2014 g.): $v 2 \mathrm{ch}$. [Topical Issues, Directions and Mechanisms of Development of Productive Forces of the North in 2014: Materials of the 4th All-Russian Seminar (Syktyvkar, September 24-26, 2014): in 2 Parts]. Syktyvkar, 2014. Part. 2. Pp. 136-144.

3. Medvedeva O.N., Frolov O.V. Sistemy avtonomnogo gazosnabzheniya [Self-Contained Gas Supply Systems]. Novye idei novogo veka: materialy Mezhdunarodnoi nauchnoi konf. [New Ideas for the New Century: Materials of International Scientific Conference]. FAD TOGU, 2013. Vol. 2. Pp. 379-384.

4. Smirnov A.V. Kotloagregaty maloi moshchnosti s topkami vysokotemperaturnogo kipyashchego sloya v kommunal'noi energetike [Boilers of Small Capacity with Furnaces with High Temperature Fluidized Bed in the Utilities Sector]. Novosti teplosnabzheniya [News of Heat Supply], 2009, no. 3 (103). Available at: http://www.ntsn.ru

5. Kolobov Yu.I., Chaika L.V. Malaya energetika $v$ sisteme energosnabzheniya Respubliki Komi [Small Energy in the Energy Supply System of the Komi Republic]. Syktyvkar: Komi NTs UrO RAN, 2000. 140 p.

6. Berezin S.R., Bogacheva A.I. Tekhnologiya energosberezheniya na baze parovoi vintovoi mashiny [Eneregy-Saving Technology on the Basis of a Screw-Type Steam Engine]. Energosovet [Energy Council], 2010, no. 7 (12), pp. 33-38. Available at: http://www.energosovet.ru /bul_stat.php?num=12

7. Parovaya vintovaya mashina (PVM) dlya kombinirovannoi vyrabotki teplovoi i elektricheskoi energii [A Screw-Type Steam Engine (STSE) for Combined Generation of Heat and Electric Power]. Available at: http://www.energosovet.ru/entech.php?idd=113

8. Shchaulov V.Yu. Ob opyte vnedreniya i ekspluatatsii gazoporshnevykh mini-TETs [About the Experience of Implementing and Operating Gas Piston Mini-CHPs]. Trudy konferentsii "Malye i srednie TETs. Sovremennye resheniya" (Mosk. obl., 7-9 sentyabrya 2005 g.) [Proceedings of the Conference "Small and Medium CHPs. Modern Solutions" (Moscow Oblast, September 7-9, 2005)]. Pp. 23-36.

9. Tamarov V.V. Razvitie kogeneratsionnoi energetiki v Yaroslavskoi oblasti [Development of Cogeneration Energy in the Yaroslavl Oblast]. Energosovet [Energy Council], 2011, no. 4 (17), pp. 15-19. Available at: http://www.energosovet.ru /bul_stat.php?num=17

10. Ob utverzhdenii regional'noi programmy "Energosberezhenie i povyshenie energeticheskoi effektivnosti na territorii Respubliki Komi (2010-2020 gody)": Postanovlenie Pravitel'stva Respubliki Komi ot 30.07.2010 № 241 (red. ot 28.07.2014) [On Approval of the Regional Program "Energy Saving and Enhancement of Energy Efficiency on the Territory of the Komi Republic (2010-2020)": the Decree of the Government of the Komi Republic dated July 30, 2010 No. 241 (as Amended on July 28, 2014)]. Konsul'tantPlyus [ConsultantPlus].

11. Marinicheva O. Shchepa i pellety vmesto mazuta i uglya [Wood Chips and Pellets instead of Fuel Oil and Coal]. Teplovaya energetika [Thermal Power], 2013, no. 03 (06), p. 13; no. 04 (07), p. 11. Available at: http://www.eprussia.ru/teploenergetika/ 
12. Kotel'noe oborudovanie na biotoplive [Biomass Boiler Equipment]. LesPromInform [LesPromInform], 2008, no. 1 (50), pp. 120-127.

13. Ryabov G.A., Litun D.S. Vodogreinye kotly dlya szhiganiya drevesnykh otkhodov [Hot Water Boilers for Burning Wood Waste]. Novosti teplosnabzheniya [News of Heat Supply], 2002, no. 11, 12, pp. 12-14, 1618.

14. Trepov M.V., Shestakov S.M. Ekonomika ispol'zovaniya biotopliva [The Economics of Biomass]. LesPromInform [LesPromInform], 2007, no. 8 (48), pp. 48-52.

15. Shemyakin V.N., Karapetov A.E. Vnedrenie tekhnologii szhiganiya v kipyashchem sloe kak odin iz putei resheniya vnedreniya mestnykh nizkosortnykh topliv v energetiku strany [Introduction of Fluidised Bed Technology as a Way to Solve the Problem of Introducing Local Low-Grade Fuels in the Energy Sector of the Country]. Novosti teplosnabzheniya [News of Heat Supply], 2007, no. 9 (85). Available at: http:// www.rosteplo.ru/ Tech_stat/stat_shablon.php?id=1951

\section{Cited works}

1. The Report of Vyacheslav Gaizer, Head of the Komi Republic, to the State Council of the Komi Republic "On the Results of Performance of the Government in 2013, on the Main Directions of Work for 2014 and for the Medium Term. Available at: http://rkomi.ru/services/doklady/

2. Chaika L.V. Energy Infrastructure in Rural Settlements of the Komi Republic. Topical Issues, Directions and Mechanisms of Development of Productive Forces of the North in 2014: Materials of the 4th All-Russian Seminar (Syktyvkar, September 24-26, 2014): in 2 Parts. Syktyvkar, 2014. Part. 2. Pp. 136-144.

3. Medvedeva O.N., Frolov O.V. Self-Contained Gas Supply Systems. New Ideas for the New Century: Materials of International Scientific Conference. FAD TOGU, 2013. Vol. 2. Pp. 379-384.

4. Smirnov A.V. Boilers of Small Capacity with Furnaces with High Temperature Fluidized Bed in the Utilities Sector. News of Heat Supply, 2009, no. 3 (103). Available at: http://www.ntsn.ru

5. Kolobov Yu.I., Chaika L.V. Small Energy in the Energy Supply System of the Komi Republic. Syktyvkar: Komi NTs UrO RAN, 2000. 140 p.

6. Berezin S.R., Bogacheva A.I. Eneregy-Saving Technology on the Basis of a Screw-Type Steam Engine. Energy Council, 2010, no. 7 (12), pp. 33-38. Available at: http://www.energosovet.ru /bul_stat.php?num=12

7. A Screw-Type Steam Engine (STSE) for Combined Generation of Heat and Electric Power. Available at: http://www.energosovet.ru/entech.php?idd=113

8. Shchaulov V.Yu. About the Experience of Implementing and Operating Gas Piston Mini-CHPs. Proceedings of the Conference "Small and Medium CHPs. Modern Solutions" (Moscow Oblast, September 7-9, 2005). Pp. 23-36.

9. Tamarov V.V. Development of Cogeneration Energy in the Yaroslavl Oblast. Energy Council, 2011, no. 4 (17), pp. 15-19. Available at: http://www.energosovet.ru /bul_stat.php?num=17

10. On Approval of the Regional Program "Energy Saving and Enhancement of Energy Efficiency on the Territory of the Komi Republic (2010-2020)": the Decree of the Government of the Komi Republic dated July 30, 2010 No. 241 (as Amended on July 28, 2014). ConsultantPlus.

11. Marinicheva O. Wood Chips and Pellets instead of Fuel Oil and Coal. Thermal Power, 2013, no. 03 (06), p. 13; no. 04 (07), p. 11. Available at: http://www.eprussia.ru/teploenergetika/

12. Biomass Boiler Equipment. Les PromInform, 2008, no. 1 (50), pp. 120-127.

13. Ryabov G.A., Litun D.S. Hot Water Boilers for Burning Wood Waste. News of Heat Supply, 2002, no. 11, 12, pp. 12-14, 16-18.

14. Trepov M.V., Shestakov S.M. The Economics of Biomass. LesPromInform, 2007, no. 8 (48), pp. 48-52.

15. Shemyakin V.N., Karapetov A.E. Introduction of Fluidised Bed Technology as a Way to Solve the Problem of Introducing Local Low-Grade Fuels in the Energy Sector of the Country. News of Heat Supply, 2007, no. 9 (85). Available at: http://www.rosteplo.ru/ Tech_stat/stat_shablon. php?id=1951 